\title{
PRAKIRAAN KEBUTUHAN ENERGI LISTRIK DI KELURAHAN SUNGAI MEMPURA SEBAGAI KAWASAN EKOWISATA
}

\author{
Usaha Situmeang \\ Program Studi Teknik Elektro, Fakultas Teknik, Universitas Lancang Kuning \\ Jl. Yos Sudarso km. 8 Rumbai, Pekanbaru, Telp. (0761) 52324 \\ Email: usaha@unilak.ac.id
}

\begin{abstract}
ABSTRAK
Permasalahan dalam penelitian ini adalah memprakirakan kebutuhan energi listrik untuk daerah yang dijadikan sebagai kawasan ekowisata khususnya kelurahan Sungai Mempura yang berada di kabupaten Siak Sri Indrapura Riau. Kebutuhan energi listrik selalu dilakukan untuk mengantisipasi kebutuhan masa mendatang. Pertumbuhan penduduk dan perekonomian merupakan pemicu pertumbuhan penggunaan energilistrik. Oleh karena itu, perlu dilakukan prakiraaan kebutuhan energi listrik khususnya di kelurahan Sungai Mempura sebagai kawasan ekowisata. Teknik membuat perkiraan energi listrik umumnya mengacu kepada statistic masa lalu. Untuk itu diperlukan sebuah metoda dalam memprakirakan kebutuhan energi listrik, dimana pada penelitian ini metoda yang dipergunakan adalah regresi linear. Dari hasil penelitian ini diperoleh prakiraan kebutuhan energi listrik di kelurahan Sungai Mempura Siak Sri Indrapura Riau sebesar 3.129.236 $\mathrm{kWh}$ pada tahun 2022 dengan pertumbuhan penduduk sebesar 10,6\% dan pertumbuhan perekonomian sebesar $3,7 \%$.
\end{abstract}

Kata Kunci: Regresi linear, statistik penduduk dan ekonomi

\begin{abstract}
The problem in this study is estimates electricity needs for the region that serve as ecotourism especially for Sungai Mempura village located in the district of Riau Siak Sri Indrapura. Electricity need is always done in anticipation of future needs. Population growth and economic growth are the drivers of electricity use. Therefore, it is necessary to estimates electricity needs, especially in Sungai Mempura as ecotourism. Technique to estimate the electric power generally refers to the past statistics. For that we need a method to estimate the electricity needs, which in this research method used is linear regression. From these study results obtained forecasts of electricity needs in Sungai Mempura Siak Sri Indrapura County of 3,129,236 $k$ Wh in 2022 with a population growth of $10.6 \%$ and $3.7 \%$ economic growth.
\end{abstract}

Keywords: Linear regression, population and economic statistics

\section{PENDAHULUAN}

\section{A. Pendahuluan}

Energi listrik adalah salah satu komponen utama dalam mendukung pertumbuhan suatu daerah. Presentase konsumsi listrik juga dapat menjadi ukuran peningkatan kualitas masyarakat dan pertumbuhan ekonomi. Kecenderungan pada saat ini, peningkatan kebutuhan energi listrik tidak seiring dengan peningkatan penyediaan energi listrik, dimana kapasitas daya terpasang masih tetap, sementara kebutuhan masyarakat terus meningkat seiring dengan meningkatnya jumlah penduduk dan kegiatan pendukungnya [1].

Begitu juga halnya dengan kebutuhan listrik di Kabupaten Siak cukup tinggi dan dengan keterbatasan dana baik pemerintah, pemerintah daerah serta PLN menyebabkan terjadi kekurangan listrik dan bahkan terjadi krisis listrik. Penduduk Kabupaten Siak belum menikmati listrik 29,38\%, bahkan kecamatan Sungai Mandau 82,98\%, kecamatan Pusako 65,58\% dan kecamatan Menpura 47,04\% belum menikmati listrik pada tahun 2010 .

Seiring dengan rencana Pemerintah Daerah Siak untuk menjadikan kelurahan Sungai Menpura yang berada di kecamatan Menpura sebagai kawasan ekowisata tentunya haruslah didukung oleh ketersediaan energi listrik. Dari data yang ada pada tahun 2010 untuk kecamatan Menpura tentunya harus ada penyelesaian permasalahan dibidang ketenagalistrikan untuk menjadikan kelurahan Sungai Menpura sebagai kawasan ekowisata.

Oleh karena itu diperlukan kajian atau penelitian yang menitikberatkan terhadap sumber daya energi, tingkat kebutuhan energi listrik, laju 
pertumbuhan penduduk dan tingkat perekonomian masyarakat untuk percepatan program tersebut.

\section{METODE PENELITIAN}

Metode penelitian yang digunakan dalam penelitian ini adalah :

\section{Metode pengumpulan data}

Metode yang digunakan pada proses pengumpulan data adalah melalui proses studi pustaka, survey lapangan, dan wawancara seperti :

a. Data gambaran umum kelurahan Sungai Mempura Siak Sri Indrapura

b. Data Pertumbuhan Penduduk

c. Data kebutuhan tenaga listrik

d. Data Pertumbuhan Ekonomi

\section{Metode Pengolahan data}

Metode pada pengolahan data bersifat kuantitatif.

a. Metode pengumpulan data dari metode penelitian kuantitatif dengan menggunakan metoda regresi linear $(\mathrm{Y}=\mathrm{a}+\mathrm{bX})$

b. Perhitungan dilakukan secara manual dengan bantuan program excel.

\section{Analisis data}

Metode analisis data merupakan hasil yang diperoleh dari pengumpulan data yang diproses untuk mendapatkan kebutuhan tenaga listrik di kelurahan Sungai Menpura Siak Sri Indrapura sebagai kawasan ekowisata.

Bentuk perekonomian dari bentuk ekonomi agraris menjadi ekonomi industri juga sangat berperan dalam pertumbuhan permintaan terhadap energi listrik. Hal ini disebabkan karena bentuk ekonomi industri akan melibatkan jauh lebih banyak peralatan yang menggunakan energi listrik. Pertumbuhan pemakaian energi listrik tersebut tentu saja harus disertai dengan pertumbuhan kemampuan pembangkit dalam mensuplai tenaga listrik agar tidak terjadi krisis listrik. Untuk itu, diperlukan analisis yang dapat dipercaya dalam hal mengkalkulasi kemampuan pembangkit, untuk selanjutnya dapat menjadi bahan pertimbangan akan adanya penambahan kapasitas pembangkit atau pembangunan pembangkit baru. Salah satu hal yang sangat penting dalam menentukan pengembangan sistim kelistrikan adalah perkiraan pertumbuhan permintaan energi listrik.

Salah satu hal yang sangat penting dalam menentukan pengembangan sistim kelistrikan adalah perkiraan pertumbuhan permintaan energi listrik. Permintaan energi listrik dibagi dalam empat kelompok/sekfor utama yaitu: rumah tangga industri, komerisal dan sosial/umum, sedangkan variabel yang dianggap memiliki pengaruh terhadap permintaan energi listrik antara lain Gross Domestic Product (GDP), Jumlah penduduk (POP), Penduduk Daerah Perkotaan (UPOP) dan jumlah penduduk Rumah tangga berlistrik (NHE). Juga digunakan rasio elektrifikasi (ER) yang didefinisikan sebagai presentase jumlah rumah tangga berlistrik dibagi jumlah total rumah tangga, dan rasio perkotaan (UR) sebagai variable adalah prensentase jumlah penduduk perkotaan dibagi total jumlah penduduk [2].

Penerapan statistik dalam memperkirakan kebutuhan energi listrik dimasa yang akan datang merupakan cara yang tepat mendapatkan hasil perhitungan yang mendekati sebenarnya. Macammacam persamaan dalam perkiraan daya adalah analisa kecendrungan (trend). Analisa kecendrungan ialah cara mempelajari sederet waktu atau suatu proses diwaktu yang lalu dan saat ini kemudian dibuat model matematiknya sehingga prediksi yang akan datang dapat diketahui dari sekarang [3].

\section{Prakiraan Kebutuhan Energi Listrik}

Prakiraan atau forecast pada dasarnya merupakan dugaan atau prakiraan mengenai terjadinya suatu kejadian atau peristiwa di waktu yang akan datang. Prakiraan bisa bersifat kualitatif (tidak berbentuk angka) maupun kuantitatif (berbentuk angka). Prakiraan kualitatif sulit dilakukan untuk memperoleh hasil yang baik karena variabelnya sangat relatif sifatnya. Prakiraan kuantitatif dibagi dua yaitu : prakiraan tunggal (point forecost) dan prakiraan selang (interval forecast). Prakiraan tunggal terdiri dari satu nilai, sedangkan prakiraan selang terdiri dari beberapa nilai, berupa suatu selang (interval) yang dibatasi oleh nilai batas bawah (prakiraan batas bawah) dan batas atas (prakiraan tinggi). Kelemahan dari prakiraan tunggal ialah bahwa nilai yang diperoleh berupa gambaran berapa jauh jarak atau selisih nilai prakiraan dengan nilai sebenarnya. Prakiraan selang dimaksudkan untuk memperkecil kesalahan hasil prakiraan dengan kenyataan.

\section{Jangka Waktu Prakiraan}

Prakiraan kebutuhan energi listrik dapat dikelompokkan menurut jangka menjadi tiga kelompok, yaitu :

a. Prakiraan jangka panjang

Prakiraan jangka panjang adalah prakiraan untuk jangka waktu diatas satu tahun. Dalam prakiraan jangka panjang masalah-maslah makro ekonomi yang merupakan masalah ekstern perusahaan listrik merupakan faktor utama yang menentukan arah prakiraan kebutuhan energi. Faktor makro tersebut diatas misalnya adalah Pendapatan Domestik Regional Bruto (PDRB). 
b. Prakiraan jangka menengah

Prakiraan jangka menengah adalah prakiraan untuk jangka waktu dari satu bulan sampai dengan satu tahun. Dalam prakiraan beban jangka menengah faktor-faktor manajerial perusahaan merupakan faktor utama yang menentukan. Masalah-masalah manajerial misalnya kemampuan teknis memperluas jaringan distribusi, kemampuan teknis menyelesaikan proyek pembangkit listrik baru serta juga kemampuan teknis menyelesaikan proyek saluran transmisi.

c. Prakiraan jangka pendek

Prakiraan jangka pendek adalah prakiraan untuk jangka waktu beberapa jam sampai satu minggu (168 jam). Dalam prakiraan jangka pendek terdapat batas atas untuk beban maksimum dan batas bawah untuk beban minimum yang ditentukan oleh prakiraan beban jangka menengah.

\section{Regresi Linear}

Teknik membuat perkiraan beban umumnya mengacu kepada statistik masa lalu dan atas dasar analisa karakteristik beban yang lalu. Disini dapat dipakai metoda Regresi Linear dalam memperkirakan kebutuhan beban [4] dapat dilihat seperti berikut :

$$
\mathrm{Y}=\mathrm{a}+\mathrm{bX}
$$

Keterangan :

$\mathrm{Y}=$ Hal yang diprediksikan

$\mathrm{a}=$ Bilangan konstan

$\mathrm{b}=$ Koefisien prediktor

$\mathrm{X}=$ Variabel prediktor

Dalam bentuk grafik pada Gambar 1, persamaan $\mathrm{Y}=$ $\mathrm{a}+\mathrm{bX}$ dapat disajikan sebagai berikut [5] :

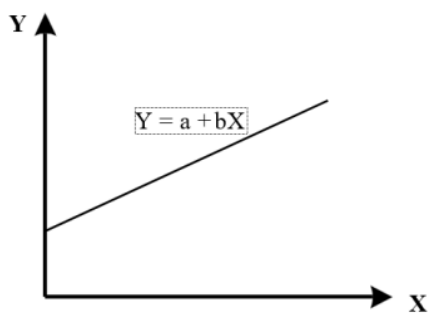

Gambar 1. Grafik persamaan regresi linear

Perhitungan persamaan regresi yang dimaksudkan diatas adalah untuk dapat melukiskan garis regresi. Untuk mengisi persamaan itu, harga koefisien prediktor (b) dan bilangan konstan (a) haruslah terlebih dahulu ditemukan, yaitu :

$$
\begin{aligned}
& b=\frac{\sum X Y-\bar{X} \sum Y}{\sum X^{2}-\bar{X} \sum X} \\
& a=\bar{Y}-b \bar{X}
\end{aligned}
$$

Untuk melihat besarnya ketepatan dari metoda regresi dilakukan pengujian, seperti persamaan berikut :

$$
\begin{aligned}
& \sum y^{2}=\sum Y^{2}-n(\bar{Y})^{2} \\
& \sum x^{2}=\sum X^{2}-n(\bar{X})^{2}
\end{aligned}
$$

Sehingga :

$$
\sum e^{2}=\sum y^{2}-b^{2}\left(\sum x^{2}\right)
$$

Maka $: R^{2}=1-\frac{\sum e^{2}}{\sum y^{2}}$

Keterangan :

$\Sigma \mathrm{y}^{2}=$ jumlah kuadrat total perbedaan $\mathrm{Y}$ dari $\bar{Y}$

$\Sigma \mathrm{X}^{2}=$ Variasi $\mathrm{Y}$ yang dapat diterangkan oleh Variasi $\mathrm{X}$

$\Sigma \mathrm{e}^{2}=$ Variasi $\mathrm{Y}$ yang bisa dijelaskan oleh Variasi $\mathrm{X}$

$\mathrm{R}^{2}=$ Koofisien determinasi (Derarjat ketepatan)

\section{Prakiraan Pertumbuhan Beban Listrik}

Prakiraan pertumbuhan beban listrik pada dasarnya adalah untuk mengetahui beban maksimum suatu sistem distribusi energilistrik pada perencanaan penambahan daya. Oleh sebab itu, suatu perkiraan tidak selalu tepat $100 \%$, sehingga data perkiraan di dalam penggunaannya masih memerlukan pertimbangan-pertimbangan dari para pemakai.

Perkiraan biasanya didasarkan atas asumsiasumsi. Kalau asumsi tersebut benar, maka hasil perkiraan mungkin benar. Akan tetapi, kalau asumsi/keadaan berubah, maka hasil perkiraan itu jelas akan berubah. Perubahan itu membuat hasil perkiraan menaik atau menurun tergantung pada faktor yang berubah.

Disamping itu, perlu disadari bahwa jangka waktu berlakunya suatu perkiraan juga sangat berpengaruh. Sebab semakin jauh kedepan perkiraan itu, semakin besar kesalahan yang mungkin dibuat. Akibatnya, makin besar pula unsur ketidakpastiannya. Oleh karena itu, sebaiknya dilakukan pembaharuan setiap kali ada data baru yang sudah selesai dikumpulkan. Dengan bantuan teknik dan metoda perkiraan yang ada, diharapkan kesalahan-kesalahan yang mungkin timbul dapat diminimumkan. 
Kemudian untuk menentukan kebutuhan ratarata tenaga/energi listrik $\mathrm{kWh} / \mathrm{jiwa}$ ditulis dengan persamaan :

\section{Jumlah konsumsi kWh rata-rata/tahun}

Jumlah Penduduk rata-rata/tahun

\section{HASIL DAN PEMBAHASAN}

\section{Data dan Objek Pembahasan}

Wilayah kelurahan Sungai Mempura merupakan wilayah yang terletak di kecamatan Mempura yang pada umumnya terdiri dari dataran rendah dan berbukit-bukit dengan struktur tanah pada umumnya terdiri dari tanah podsolik merah kuning dari batuan dan aluvial serta tanah organosol dan gley humus dalam bentuk rawa-rawa atau tanah basah.

Hampir seluruh desa di Kecamatan Mempura berada di daerah aliran sungai yaitu Sungai Mempura, sehingga dengan demikian sebagian besar wilayahnya merupakan dataran rendah. Demikian pula dengan keseharian penduduk wilayah ini, banyak pula yang menggantungkan kehidupan mereka dengan memanfaatkan keberadaan Sungai Mempura. Peta keluarahan Sungai Mempura seperti pada Gambar 2.

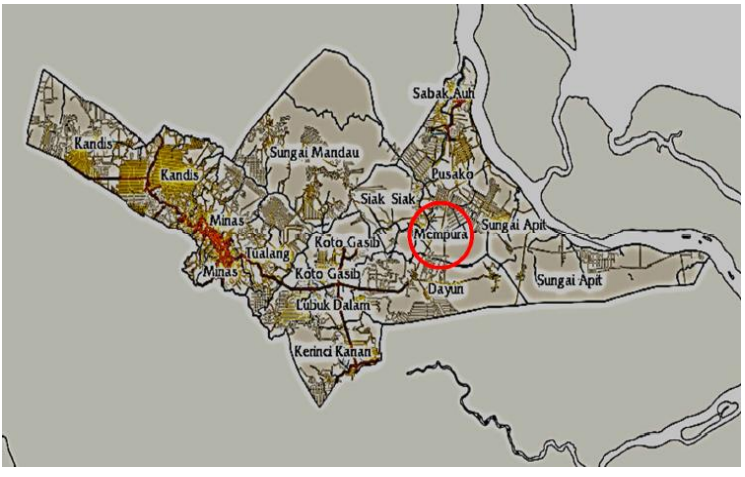

Gambar 2. Peta kelurahan Sungai Mempura yang berada di kecamatan Mempura

Luas wilayah kelurahan Sungai Mempura adalah 31.341 Ha dengan 5 Rukun Warga (RW) dan 14 Rukun Tengga (RT). Kelurahan Sungai Mempura mempunyai jaraka antara ibukota kecamatan Mempura 4,0 km dimana batas kelurahan Sungai Mempura sebagai berikut :

- Utara berbatasan dengan Sungai Siak

- Selatan berbatasan dengan kecamatan Dayun

- Barat berbatasan dengan Merempan

- Timur berbatasan dengan Kp. Tengah

Pertumbuhan penduduk merupakan salah satu faktor yang mempengaruhi pertumbuhan energi listrik. Oleh karena itu pertumbuhan penduduk kelurahan Sungai Mempura diproyeksikan untuk mengetahui besarnya peningkatan penduduk yang terjadi dan proyeksi ini dilihat dari data historis pertumbuhan penduduk tahun 2008-2012 seperti pada Tabel 1.

Tabel 1. Data Pertumbuhan Penduduk Kel. Sungai Mempura

\begin{tabular}{ccc}
\hline No. & Tahun & Jumlah penduduk \\
\hline 1 & 2008 & 3.569 \\
2 & 2009 & 3.570 \\
3 & 2010 & 3.593 \\
4 & 2011 & 4.013 \\
5 & 2012 & 4.004 \\
\hline
\end{tabular}

Sumber: BPS Siak

Selanjutnya pertumbuhan penduduk di kelurahan Sungai Mempura Siak Sri Indrapura dari tahun 2008 hingga 2012 dalam bentuk grafik seperti pada Gambar 3.

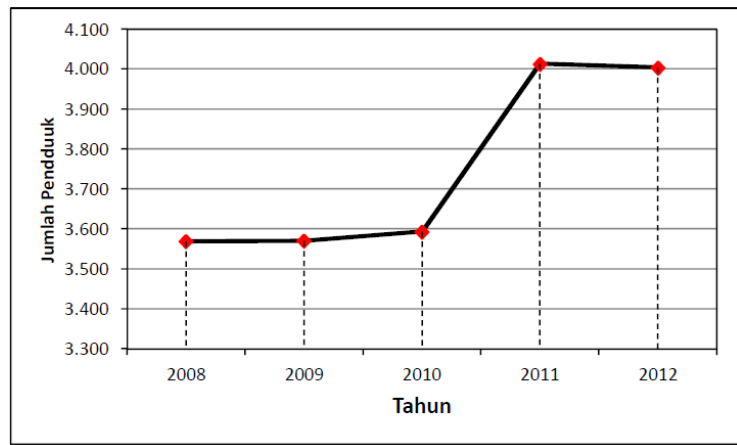

Gambar 3. Grafik Pertumbuhan penduduk di kelurahan Sungai Mempura

Selain pertumbuhan penduduk, pertumbuhan ekonomi juga merupakan faktor yang mempengaruhi kebutuhan tenaga/energi listrik. Sehingga pertumbuhan ekonomi juga diproyeksikan untuk mengetahui pertumbuhan ekonomi. Data historis dari Pendapatan Domestik Regional Bruto (PDRB) kelurahan Sungai Mempura seperti pada Tabel 2.

Tabel 2. PDRB Kelurahan Sungai Mempura

\begin{tabular}{ccc}
\hline No & Tahun & PDRB (juta Rp.) \\
\hline 1 & 2008 & $29.600,33$ \\
2 & 2009 & $31.717,51$ \\
3 & 2010 & $34.052,71$ \\
4 & 2011 & $36.592,24$ \\
5 & 2012 & $39.349,83$ \\
\hline
\end{tabular}

Adapun data historis dari konsumsi tenaga/energi listrik di kelurahan Sungai Mempura seperti pada Tabel 3. 
$\underline{\text { Tabel 3. PDRB Kelurahan Sungai Mempura }}$

\begin{tabular}{cccc}
\hline No & Tahun & $\begin{array}{c}\text { Jumlah } \\
\text { Pelanggan }\end{array}$ & $\begin{array}{c}\text { Penggunaan } \\
(\mathrm{kWh})\end{array}$ \\
\hline 1 & 2008 & 772 & 1.685 .698 \\
2 & 2009 & 803 & 1.832 .280 \\
3 & 2010 & 892 & 2.234 .488 \\
4 & 2011 & 983 & 2.330 .575 \\
5 & 2012 & 1128 & 2.668 .887 \\
\hline
\end{tabular}

\section{Pembahasan}

Dari data historis penduduk kelurahan Sungai Mempura pada Tabel 1. dilakukan proyeksi atau prakiraan jumlah penduduk dengan menggunakan regresi linier dan didapatkan koefisien regresi seperti pada Tabel 4. Proyeksi pertumbuhan penduduk tahun berikutnya dari tahun 2013 hingga tahun 2022 seperti pada Tabel 5.

Dari data pada Tabel 5 diperoleh nilai-nilai sebagai berikut :

$$
\begin{array}{lll}
\Sigma n=5 & & \\
\Sigma X=10 & \Sigma Y=18.749 & \\
\Sigma X^{2}=30 & \Sigma Y^{2}=70.528 .495 & \Sigma X Y=38.811
\end{array}
$$

Selanjutnya dengan mempergunakan persamaan regresi linear $\mathrm{Y}=\mathrm{a}+\mathrm{bX}$ dapat diperoleh hasil sebagai berikut :

$$
\begin{aligned}
b & =\frac{\sum X Y-\bar{X} \sum Y}{\sum X^{2}-\bar{X} \sum X} \\
& =\frac{38.811-(2 \times 18.749)}{30-(2 \times 10)} \\
& =131,3 \\
a & =\bar{Y}-b \bar{X} \\
& =3.749,80-(131,3 \times 2) \\
& =3487,2
\end{aligned}
$$

Proyeksi pertumbuhan jumlah penduduk pada 2013

\begin{tabular}{|c|c|c|c|c|c|c|}
\hline No & Tahun & Jml Penduduk (Y) & $X$ & $\mathrm{X}^{2}$ & $\mathrm{Y}^{2}$ & X.Y \\
\hline 1 & 2008 & 3.569 & 0 & 0 & 12.737 .761 & 0 \\
\hline 2 & 2009 & 3.570 & 1 & 1 & 12.744 .900 & 3.570 \\
\hline 3 & 2010 & 3.593 & 2 & 4 & 12.909 .649 & 7.186 \\
\hline 4 & 2011 & 4.013 & 3 & 9 & 16.104 .169 & 12.039 \\
\hline 5 & 2012 & 4.004 & 4 & 16 & 16.032 .016 & 16.016 \\
\hline \multicolumn{2}{|c|}{ Jumlah $\left(\sum\right)$} & 18.749 & 10 & 30 & 70.528 .495 & 38.811 \\
\hline
\end{tabular}
dan tahun 2014 adalah sebagai berikut :

$$
\begin{aligned}
& Y_{2013}=3487,2+(131,3 \times 6)=4.275 \\
& Y_{2014}=3487,2+(131,3 \times 7)=4.406
\end{aligned}
$$

Dengan cara yang sama, untuk proyeksi pertumbuhan penduduk tahun berikutnya dari tahun 2015 hingga tahun 2022 seperti pada Tabel 5.

Maka diperoleh :

$$
\begin{aligned}
& \bar{X}=\frac{\sum X}{n}=\frac{10}{5}=2 \\
& \bar{Y}=\frac{\sum Y}{n}=\frac{18.749}{5}=3.749,80
\end{aligned}
$$

Tabel 4. Koofisien Regresi Pertumbuhan Penduduk Kelurahan Sungai Mempura

Tabel 5. Proyeksi Pertumbuhan Penduduk Kelurahan Sungai Mempura

\begin{tabular}{ccccccc}
\hline No. & Tahun & $\mathrm{a}$ & $\mathrm{b}$ & $\mathrm{n}$ & Jml Pddk & Kenaikan $(\%)$ \\
\hline 1 & 2013 & 3487,2 & 131,3 & 6 & 4.275 & 6,3 \\
2 & 2014 & 3487,2 & 131,3 & 7 & 4.406 & 3,0 \\
3 & 2015 & 3487,2 & 131,3 & 8 & 4.538 & 2,9 \\
4 & 2016 & 3487,2 & 131,3 & 9 & 4.669 & 2,8 \\
5 & 2017 & 3487,2 & 131,3 & 10 & 4.800 & 2,7 \\
6 & 2018 & 3487,2 & 131,3 & 11 & 4.932 & 2,7 \\
7 & 2019 & 3487,2 & 131,3 & 12 & 5.063 & 2,6 \\
8 & 2020 & 3487,2 & 131,3 & 13 & 5.194 & 2,5 \\
9 & 2021 & 3487,2 & 131,3 & 14 & 5.325 & 2,5 \\
\hline
\end{tabular}


Kemudian dari data pada Tabel 5 diperoleh grafik perkiraan atau proyeksi pertumbuhan penduduk di Kelurahan Sungai Mempura seperti pada Gambar 4.

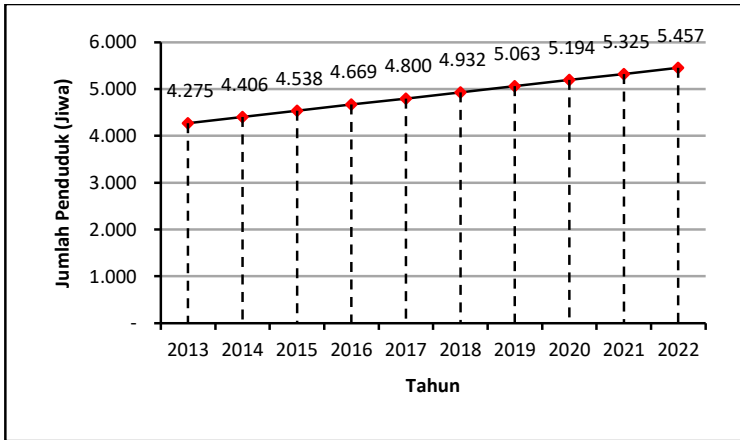

Gambar 4. Grafik Proyeksi Pertumbuhan Penduduk Kelurahan Sungai Menpura

Untuk melihat besarnya ketepatan dari metoda regresi linear ini dilakukan pengujian sebagai berikut :

$$
\begin{aligned}
\Sigma y^{2} & =\sum Y^{2}-n(\bar{Y})^{2} \\
& =70.528 .495-(5)(3.749,80)^{2} \\
& =223.495 \\
\Sigma \mathrm{x}^{2} & =\Sigma \mathrm{X}^{2}-(\overline{\mathrm{X}})^{2} \\
& =30-(5)(2)^{2} \\
& =10
\end{aligned}
$$

$$
\begin{aligned}
\Sigma e^{2} & =\Sigma y^{2}-b^{2}\left(\sum x^{2}\right) \\
& =223.495-(131,3)^{2}(10) \\
& =51.098
\end{aligned}
$$

$$
\begin{aligned}
R^{2} & =1-\frac{\sum e^{2}}{\sum y^{2}} \\
& =1-\left(\frac{51.098}{223.495}\right)
\end{aligned}
$$

\begin{tabular}{|c|c|c|c|}
\hline & Tahun & Jumlah Penduduk & Kebutuhan kWh \\
\hline & 2013 & 4.275 & 2.451 .570 \\
\hline & 2014 & 4.406 & 2.526 .866 \\
\hline & 2015 & 4.538 & 2.602 .163 \\
\hline & 2016 & 4.669 & 2.677 .459 \\
\hline & 2017 & 4.800 & 2.752 .755 \\
\hline & 2018 & 4.932 & 2.828 .051 \\
\hline & 2019 & 5.063 & 2.903 .347 \\
\hline & 2020 & 5.194 & 2.978 .644 \\
\hline & 2021 & 5.325 & 3.053 .940 \\
\hline & 2022 & 5.457 & 3.129 .236 \\
\hline \multirow{7}{*}{ 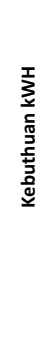 } & \multirow{6}{*}{$\begin{array}{r}3.500 .000 \\
3.000 .000 \\
2.500 .000 \\
\\
2.000 .000 \\
1.500 .000 \\
\\
1.000 .000 \\
500.000\end{array}$} & & \\
\hline & & & \\
\hline & & & \\
\hline & & & \\
\hline & & 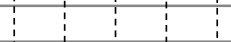 & 4 \\
\hline & & 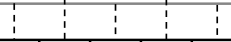 & 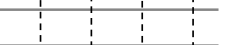 \\
\hline & & 2013201420152016201 & 3019202020212022 \\
\hline
\end{tabular}$$
=0,771
$$

Nilai $R^{2}$ akan semakin baik apabila nilai yang diperoleh mendekati 1 .

\section{Prakiraan/Proyeksi Kebutuhan Energi Listrik}

Kemudian proyeksi konsumsi energi listrik (kWh) di Kelurahan Sungai Mempura untuk tahun 2013 sampai dengan 2022 dihitung diberikan pada Tabel 6.
Tabel 6. Proyeksi Konsumsi tenaga/energi Listrik (kWh) Sei Mempura

Gambar 5. Grafik proyeksi konsumsi energi listrik di kelurahan Sungai Mempura dari tahun 2013 sampai dengan 2022

Proyeksi pertumbuhan ekonomi di kelurahan Sungai Mempura seperti pada Tabel 7. Selanjutnya dari data pada Tabel 7 diperoleh grafik perkiraan atau proyeksi pertumbuhan Ekonomi di Kelurahan Sungai Mempura seperti pada Gambar 6.

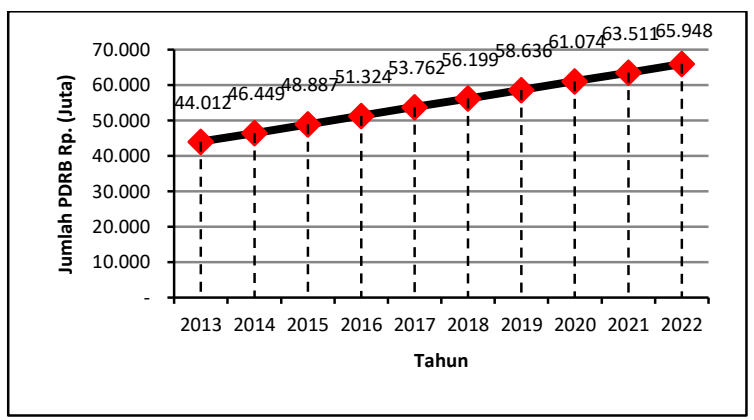

Gambar 6. Grafik proyeksi pertumbuhan ekonomi di kelurahan Sungai Mempura dari tahun 2013 sampai dengan 2022

Bila proyeksi/prakiraan konsumsi energi listrik di kelurahan Sungai Mempura dengan pertimbangan atau memperhatikan pertumbuhan penduduk dan pertumbuhan ekonomi, dapat dilakukan dengan menggunakan persamaan :

$$
\begin{gathered}
P_{n}=Q\left(1+R_{n}\right) \text { atau } \\
P_{n}=k \text { onsumsi }(k W h)\left(1+\Delta E K_{n}\right)
\end{gathered}
$$


Untuk Proyeksi tahun 2013 sampai dengan tahun 2022 seperti pada Tabel 8. Dari data pada Tabel 8 diperoleh grafik prakiraan atau proyeksi pertumbuhan penduduk, ekonomi dan kebutuhan tenaga listrik $(\mathrm{kWh})$ di Kelurahan Sungai Mempura seperti pada Gambar 7.

Tabel 7. Proyeksi Pertumbuhan Ekonomi

\begin{tabular}{ccccccc}
\hline No. & Tahun & $\mathrm{a}$ & $\mathrm{b}$ & $\mathrm{n}$ & $\begin{array}{c}\text { Jumlah PDRB } \\
\text { ( jt Rp.) }\end{array}$ & Kenaikan (\%) \\
\hline 1 & 2013 & $29.387,78$ & $2.437,37$ & 6 & 44.012 & 10,6 \\
2 & 2014 & $29.387,78$ & $2.437,37$ & 7 & 46.449 & 5,2 \\
3 & 2015 & $29.387,78$ & $2.437,37$ & 8 & 48.887 & 5,0 \\
4 & 2016 & $29.387,78$ & $2.437,37$ & 9 & 51.324 & 4,7 \\
5 & 2017 & $29.387,78$ & $2.437,37$ & 10 & 53.762 & 4,5 \\
6 & 2018 & $29.387,78$ & $2.437,37$ & 11 & 56.199 & 4,3 \\
7 & 2019 & $29.387,78$ & $2.437,37$ & 12 & 61.074 & 4,2 \\
8 & 2020 & $29.387,78$ & $2.437,37$ & 13 & 63.511 & 3,0 \\
9 & 2021 & $29.387,78$ & $2.437,37$ & 14 & 65.948 & 3,7 \\
10 & 2022 & $29.387,78$ & $2.437,37$ & 15 & & \\
\hline
\end{tabular}

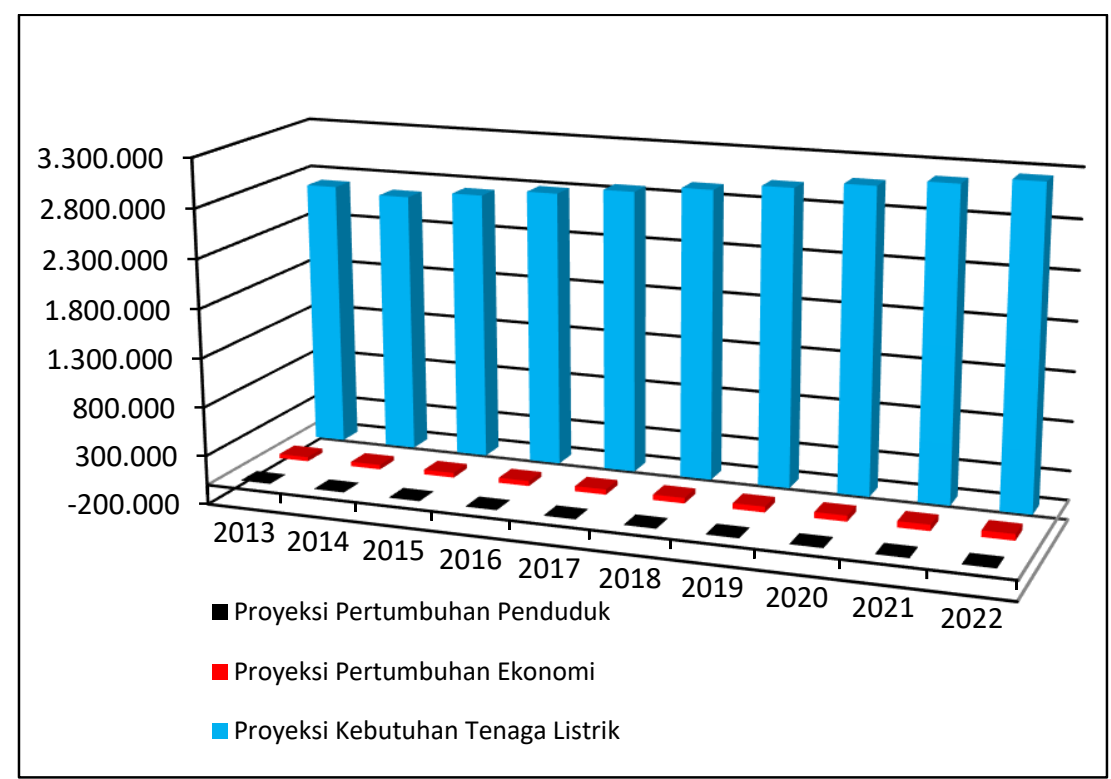

Gambar 7. Grafik proyeksi pertumbuhan penduduk, ekonomi dan kebutuhan energi listrik di kelurahan Sungai Mempura dari tahun 2013 sampai dengan 2022

Tabel 8. Proyeksi Kebutuhan Energi Listrik berdasarkan Pertumbuhan Penduduk \& Ekonomi di kelurahan Sungai Mempura

\begin{tabular}{cccccc}
\hline Thn & $\begin{array}{c}\text { Penduduk } \\
\text { (Jiwa) }\end{array}$ & $\begin{array}{c}\text { Ekonomi } \\
\text { (Juta) }\end{array}$ & $\mathrm{kWh}$ & \multicolumn{2}{c}{ Laju Pertumbuhan $(\%)$} \\
Penduduk & Ekonomi \\
\hline 2013 & 4.275 & 44.012 & 2.711 .265 & 6,3 & 10,6 \\
2014 & 4.406 & 46.449 & 2.659 .461 & 3,0 & 5,2 \\
2015 & 4.538 & 48.887 & 2.731 .900 & 2,9 & 5,0 \\
2016 & 4.669 & 51.324 & 2.804 .611 & 2,8 & 4,7 \\
2017 & 4.800 & 53.762 & 2.877 .556 & 2,7 & 4,5 \\
2018 & 4.932 & 56.199 & 2.950 .705 & 2,7 & 4,2 \\
2019 & 5.063 & 58.636 & 3.024 .033 & 2,6 & 4,0 \\
2020 & 5.194 & 61.074 & 3.097 .518 & 2,5 & 3,8 \\
2021 & 5.325 & 63.511 & 3.171 .141 & 2,5 & 3,7 \\
2022 & 5.457 & 65.948 & 3.244 .889 & 2,4 & 4,38 \\
\hline
\end{tabular}




\section{KESIMPULAN}

Kebutuhan energi listrik di kelurahan Sungai Mempura pada tahun 2022 mencapai $3.244 .889 \mathrm{kWh}$ dengan pertumbuhan penduduk rata-rata pertahun dari tahun 2013 hingga 2022 sebesar 3,04\% dan pertumbuhan ekonomi rata-rata pertahun sebesar $4,38 \%$.

\section{DAFTAR PUSTAKA}

[1] Marsudi, Djiteng, lr, 1997, Pembangkit Energi Listrik, PT. Jalamas Berkatama dan STT-YPLN Jakarta.
[2] Tadjuddin Hamdany, 2011, Proyeksi Kebutuhan Daya Listrik di Propinsi Sulawesi Tengah Tahun 2007-2020, Jurnal Ilmiah Foristek Vol.1, No. 1.

[3] Arfita Yuana Dewi, 2012, Prediksi Kebutuhan Energi Listrik Kota Padang Sampai Tahun 2020, Jurnal Teknik Elektro ITP, Volume. 1, No. 1.

[4] Kasmir, SE,MM, Jakfar, SE,MM, 2003, Studi Kelayakan Bisnis, Prenada Media, Jakarta.

[5] Cekmas Cekdin, 2005, Teori dan Contoh Soal Teknik Elektro Menggunakan Bahasa Pemrograman Matlab, Andi, Yogyakarta. 